\title{
DIE INVLOED VAN DIE REG OP ONS SUID-AFRIKAANSE BESKAWINGSPATROON
}

Die vraag of die reg ons beskawingspatroon beïnvloed kan sonder veel omhaal van woorde bevestigend beantwoord word as ons, uitgaande van bepaalde verskynsels eie aan ons beskawingspatroon, teikens aantoon dat daar regsbepalinge bestaan wat 'n conditio sine qua non is vir die bestaan van bepaalde aspekte van ons Suid-Afrikaanse lewenswyse. 'n Indrukwekkende dog vervelige lang lys van gemeenregtelike en wetteregtelike bepalinge sou dan aan $u$ voorgehou kan word as voorwaardelik vir die bestaan van bepaalde verskynsels. Die gevaar bestaan egter dat onder die magdom van woorde noodsaaklik vir die voltooiing van hierdie indeks van regsoorsake met voortvloeiende gevolge binne die kader van wat ons beskawingspatroon genoem word, 'n breër perspektief verskuil gaan en ander bydraende faktore misgekyk word. Deur hierdie benaderingswyse sou tewens ook 'n aanmatigend belangrike plek en invloedsfeer aan die juridiese toegedig word. Die legalistiese beskouing dat die reg as 'n soort selfgenoegsame grootheid met een pennestreep gehele biblioteke tot rommelpapier kan reduseer, soos Von Kirchmann in sy op. spraakwekkende geskrif: „Die Wertlosigkeit der Jurisprudenz als Wissenschaft" beweer, gaan mank aan die gebrek van eensydigheid en oormatige veralgemening. Dit is wel waar dat die staat, wat om begryplike redes by uitstek regsvormend optree, die beskawingspatroon kan beïnvloed of selfs geweld kan aandoen. Maar dan kan veelal tereg die vraag gestel word of die reg as sodanig die bron is van die abrupte breuk met of verandering in die bestaande orde van sake. Heel dikwels sal gevind word dat die aldus gepositiveerde reg in diens gestel is van bepaalde ideologiese oogmerke. ' $n$ Goeie voorbeeld hiervan tref ons aan in die Duitse Strafwetboek soos dit daar uitgesien het gedurende die Nasionaal-Sosialistiese regime. Paragraaf 2 van hierdie strafwetboek het gelui „Bestraft wird, wer eine Tat begeht, die das Gezetz für strafbar erklärt oder die nach dem Grundgedanken eines Strafgesetzes und nach gesunden Volksempfinden Bestrafung verdient". 'n Nederlandse strafregjuris (Van Bemmelen en Van Hattum - Hand- en Leerboek van het Nederlandse Strafrecht, Deel 1, p. 77) lewer 
tereg die volgende kommentaar. „Hoe bedenklijk een dergelijke formulering... is springt wel zeer in het oog wanneer we bij een gezaghebbende Duits jurist... lezen dat die gezunde Volksanshauung in allen Fällen zu identifizieren (ist) mit Grundsätzen, die dem Parteiprogramm entsprechen'." My instemming met hierdie laaste opmerking moet egter nie interpreteer word asof ek die feitlik bestaande algemene opvatting 'n staanplek in die reg wil ontsê nie. Die algemene opvatting bv. van wat passend en behoorlik is kom heel dikwels ter sprake wanneer terme soos ongewens, sedebederwend ens uitleg noodsaaklik maak, maar dan het ons te doen met ' $n$ bepaalde bron, hoewel ongeskrewe, van geldende reg; en die regter wat sy persoonlike opvatting hier laat prevaleer, handel regtens onjuis. Hieruit vloei voort dat bepaalde wetgewing eers reg daarstel namate die regsin deur uitleg vasgestel is, en by hierdie interpretasie is dit nie slegs die woorde van die wet wat in ö̈nskou geneem moet word nie, maar vele ander samehangende oorweginge, waaronder die algemene opvatting, die historiese agtergrond en so meer.

Tot dusver het ons slegs heel enkele probleme wat die verband tussen reg en beskawing raak aangesny. 'n Verdere vraag wat in die verband belangrik is geld die ontstaansmoment van reg en beskawing. Nogg die reg nóg die beskawing is staties - beide gaan onder die druk van veelvuldige faktore in meerdere of mindere mate ontwikkelingsfases deur. Die pendulum wat deur die eeue heen en weer swaai tussen aksie en reaksie, tussen verval en hervorming, sleur sowel die reg as die beskawing met hom mee. Die vraag is egter: volg die beskawing die reg of gaan die beskawing die reg vooraf? Word reg en beskawing as min of meer globale begrippe gebesig, meen ek dat daar chronologies nie 'n verskil in ontstaansmoment aan te toon is nie, en dit is selfs twyfelagtig of 'n ontstaansmoment ,überhaupt" bespeur kan word. Oppervlakkig beskou sou gesê kon word dat by die primitiewe mens reeds die reg te voorskyn tree omdat elke samelewingsverband, hoe klein en ongekompliseerd ook al, behoefte het aan ordening terwyl van ' $n$ beskawing in hierdie stadium nog lank nie sprake is nie - derhalwe dat die reg voor die beskawing was en eersgenoemde dus laasgenoemde sou beïnvloed het. 'n Kousale verband tussen primitiewe reg en beskawing wil ek nie sonder meer as onmoontlik wegwys nie, 
maar dit is tog erg onwaarskynlik dat die infantiele (i.c. die primitiewe reg) die tot meer volwassenheid gekome lewenspatroon sou beïnvloed. Hiermee kom ons meteens by die betekenis van die woord "beskawing”. Beskawing is kultuur ontplooi tot 'n hoër maat van verfyning. H. G. Stoker (Beginsels en Metodes in die Wetenskap, bl. 193) stel dit enigsins anders wanneer hy opmerk: „Kultuur kan wees: i. primitief (en dus aan ' $n$ minimum ontplooiing van menslike heerskappy deel hê; dit kan onbeskaaf wees); ii. dit kan beskaaf wees (waarby menslike heerskappy tot sy aangewese ontplooiing kom); en dit kan iii. oorbeskaaf wees (waarby die mens hom met behulp van sy beheersingstegniek verslaaf aan bv. selfsug of rykdom of mag of eer of seks of wellus of sport of kuns of wetenskap of politiek of wat ook al). Beskawing is beskaafde kultuur, één van die drie genoemde tipes of vorms van kultuur". Met Dooyeweerd (Inleiding tot de Encyclopaedie der Rechtswetenschap, p. 71) sal ons onder die kulturele weer kan verstaan „een beheersende wijze van vormgeving aan een voorgegeven materiaal naar een vrij ontwerp". Aan hierdie beheersing deur vormgewing wat Dooyeweerd beskou as die modale sinkern van die historiese aspek, het benewens clie taalkundige, estetiese, sosiale, ekonomiese en die sedelike werkseenhede van die mens ook die juridiese 'n deel. Aldus is die regsvorming gegrond op die historiese kultuurvorming in sy ontsluiting tot beskawing. Regsvorming is dus nie los te maak van kultuurvorming nie. Enigsins anders gestel: 'n blik op die ontsluiting van die reg in sy ontwikkeling tot groter wasdom, verfyning of verantwoordheid gee ons ' $n$ blik op een aspek, nl. die juridiese, van die ontsluiting van kultuur tot beskawing. ' $n$ Bepaalde beskawingspatroon word dus in een van sy fasette weerspieël deur die reg.

In die lig hiervan kom twee vrae aan die orde:

(1) Wat moet verstaan word onder die invloed van die reg op ons beskawingspatroon, en (2) wanneer is sodanige invloed aan te toon? Die antwoord op die eerste vraag meen ek volg betreklik duidelik uit die konklusie waartoe ons reeds gekom het, dat die reg een aspek of faset van die beskawingspatroon is. Die invloed van die reg op die beskawingspatroon is dus die invloed van die reg op alle aspekte van die beskawingspatroon - dus die invloed van die reg in die eerste 
plek op die ander aspekte (as die juridiese) van die beskawingspatroon, maar in die tweede plek - en dit is belangrik ook die invloed van vroeëre reg op latere reg, want die reg is immers ook 'n aspek van die beskawingspatroon.

Te veel klem sal ek darem nie in die orige deel van my betoog laat val op hierdie invloed van vroeëre reg op latere reg nie, want dan sal ek my skuldig maak aan die gebruikmaking van 'n Deus ex machina om te ontkom aan die probleme deur die onderwerp gestel.

Die tweede vraag, nl. wanneer invloed uitgaande van die reg openbaring vind in ons beskawingspatroon, is nie so maklik uit te maak nie. Aan die waarheid dat die reg kragtens sy inherente eie aard, nl. sy gerigtheid tot ordening, eerder 'n naloper as 'n voorloper is, kan ons nie ontkom nie. ' $n$ Vader gaan nie 'n lywige reglement vir sy kind opstel waarin bv. die reël voorkom: „jy mag nie met 'n potlood die mure bekrap nie". Hierdie reël sal normaalweg eers aan die kind gestel word wanneer hy reeds die mure met sy gekrabbel "versier" het. So bv. het die regsvormer van die verlede in sy beskerming of bestendiging van die huwelik rekening kon hou met owerspel maar nie met die euwel van kunsmatige inseminasie nie. Kernagtig gestel - die regsvormer gryp nie in met verordening op verordening voordat ordening noodsaaklik is nie. In die sin sou met veel vrug gevra kon word na die invloed van die beskawing of wanbeskawing op die reg. Hiermee is ons terug by die vraag of die reg die beskawing vooruitloop of volg. Sonder om die onlosmaaklike verband tussen reg en beskawing geweld te wil aandoen, wil ek die stelling waag dat die reg in sy ontsluiting selde die kulturele ontsluiting tot beskawing vooruitloop, maar dat die kulturele bloei tot beskawing heel dikwels 'n disharmonie laat wat roep om harmonisering deur die reg. Ek gebruik die woorde „selde” en "heel dikwels" hier met opset omdat ek nie kategories kulturele ontsluiting voor regsontplooiing wil plaas nie, maar slegs om dit duidelik te stel dat die reg, hoewel nie staties nie tog darem altyd 'n groot mate van konserwatisme vertoon

- 'n konserwatisme wat in die strewe na regsekerheid dikwels die indruk skep van onnodige traagheid om noodsaaklike aanpassing aan te durf. Miskien lê agter hierdie traagheid en konserwatisme ' $n$ vrees dat bewaarheid mag word wat in die 
spreuk "summum jus, summa injuria” (die hoogste reg bevat die grootste mate van onreg) beliggaam is. (Hierdie klag word terloops ook somtyds in ons fakulteitsrade gehoor wanneer 'n ontdekte leemte in ons regulasies verbetering noodsaaklik maak. Dikwels word dan gekla oor die reglementering van alles en nog wat).

Hoe traag die reg is om te lei in stede van te volg blyk uit die volgende stelling van Sohm wat betrekking het op die ontwikkeling van die Romeinse reg van 450 v. Chr. tot 565 na Chr. - dus iets meer as 'n duisend jaar: „The exigencies of commerce demanded new regulations. How to represent these regulations as virtually contained in, and covered by the statutory force of the law of the Twelve Tables, was thus the problem to be solved. The notion of formally superseding the law of the Twelve Tables, which was statutory, by conflicting rules of law which were merely customary, would at that time, have appeared unconceivable to the Romans. For throughout the long period of one thousand years, extending down to the final stage in the development of Roman law, the legal force of the Twelve Tables, as the source of all Roman law, was regarded all along as remaining, in theory, unimpaired, in spite of the fact that, when the end came, there was not a stone in the entire structure of the decemviral laws but had long been displaced from its original position, and this was quite in keeping with the conservatism of the Romans and the extreme caution with which they proceeded in all matters of law. Not one letter of the Twelve Tables was to be altered, yet the new spirit was to be infused into the old letter".

Met hierdie paar inleidende opmerkings het ek probeer aantoon dat die invloed van die reg op die beskawing nie altyd maklik aan te wys is nie, dat waar dit wel aan te wys is die reg as sodanig dikwels meer invloedsmiddel as invloedsbron is en dat regsvorming oor die algemeen ex post (d.w.s. agterna) geskied, en nie ex ante (vantevore) nie. Met dit alles in gedagte, kom ek nou by die meer konkrete behandeling van die onderwerp.

Die Suid-Afrikaanse reg het sy wortels in die Romeinse reg, die Germaanse reg, 'n vermenging van die twee nl. die Romeins-Hollandse reg, en die Engelse reg. Ook ons Suid- 
Afrikaanse beskawingspatroon het sy wortels in die verlede. Sekere ontwikkelingstendense van die ou kultuursentra van die wêreldgeskiedenis het oorgegaan in die Middeleeuse en Westerse kultuur, waardeur in bevrugting van die Germaanse kulture geheel nuwe beskawingsvorme voortgebring is. Ons eie beskawing kan hiervan nie losgemaak word nie, hoewel dit eiesoortige karaktertrekke openbaar. Bewus daarvan dat ons kultuurgeskiedenis veel verder die verlede ingryp as Rome, gaan ek my tog beperk tot Rome as beginpunt en wel omdat daar van ' $n$ noemenswaardige regsontplooiing voor hierdie tyd nie sprake is nie - bygevolg is ' $n$ invloed uitgaande van die reg op die kulturele ontplooiing voor hierdie tyd nie noemenswaardig nie.

Dit mag $u$ as vreemd voorkom dat ek $u$ bykans 2000 jaar wil terugvoer. Die belangrikheid van die Romeinse reg behoef egter geen apologie nie. Die Romeinse reg word vandag nog bestudeer in lande waar kodifikasie ' $n$ voldonge feit is en selfs in ' $n$ land soos Engeland waar die Romeinse reg nooit 'n belangrike vat verkry het nie. Hierdie bemoeienis met die Romeinse reg geskied „non quia Romanum, sed quia jus" nie vanweë die Romeinse daarin nie maar vanweë die regskundige daarin. Die invloed van die Romeinse reg strek dan ook door eeue heen - soseer dat Friedrich Carl van Savigny in die vorige eeu nog, een van sy werke met die titel „System des heutigen römischen Rechts" kon versier. Van soortgelyke strekking is die meer resente werk van P. Koschaker „Europa und das römische Recht" (1947). In 1950 skryf Fritz Schulz (Classical Roman Law, bl. 1) nog: „Roman private law has a very long history extending from the Twelve Tables of the fifth or fourth centuries B.C. throughout the whole space of antiquity down to Justinian's time and, further throughout the Middle Ages in both eastern and western Europe down to our times; for this law is still alive and its history not yet closed". Selfs nog meer onlangs besing Kaser (Das römische Privatrecht, Erster Abschitt) die roem van die Romeinse reg soos volg: „Von den Schöpfungen des römischen Geistes hat keine so tief und so dauerhaft auf die Nachwelt eingewirkt wie das Privatrecht. Die heutige Zivilrechtswissenschaft, das Kernstuck aller Jurisprudenz, ruht in den Ländern des europäischen Kontinents und in den von dort aus besiedelten Gebieten anderer Erdteile auf der gemeinsamen römischen 
Grundlage. Daran haben im allgemeinen auch die moderner Zivilgesetzbücher die die unmittelbare Geltung der römischen Quellen verdrängt haben, nichts geändert".

Die invloed van die Romeinse reg is tweërlei van aard, nl. die invloed deur die oorname van konkrete Romeinse regsinstellinge en die invloed van die Romeinsregtelike metode, wat deur die algemeengeldigheid wat dit verkry het ook tot openbaring kom in bronne wat streng gesproke buite die bestek van die Romeinse reg val. Terloops kan hier gemeld word dat deur gebruikmaking van hierdie einste metode van Romeinse herkoms vele inheemse Germaansregtelike instellinge bewaar gebly het van oorwoekering deur Romeinsregtelike instellinge. Oor die wetenskaplike metode van die Romeinse juris, hoe interessant ook al veral in sy verhouding tot die Hellenistiese invloed, meer bepaald beperk tot die filosofie en versinnebeeld in die retoriek van die oratores, handel ons nie verder nie, en wel omdat hierdie wetenskaplike arbeid van die Romeinse juriste vir sover dit die metodiek betref, in hoë mate geïsoleerd staan van die algemene kulturele werksaamhede van die mens van daardie tyd en daarna.

Wat die konkrete Romeinse regsinstellinge betref die volgende: By die regsvergelykende bestudering van die Romeinse en moderne regstelsels kan 'n mens nie anders nie as om sterk onder die indruk te kom van wat die kontinuïteit in die regsontwikkeling genoem word. Die verskynsel dat latere reg altyd verband bly hou met vroeëre reg en dat selfs na aanmerklike vernuwing die vernude reg nooit heeltemal nuut is nie en die ou reg nie heeltemal in die vergetelheid geraak het nie, kan nie anders as opvallend beskryf word nie. Dat daar wel verskille is, lê voor die hand, maar hierdie verskille is grotendeels te verklaar uit die verskil in beskawingspeil. Die Romeinse reg is nog gekleed in die tooisel van formalisme, hou nog rekening met die patriargale gesag van die voorvaders, is nog verknog aan die onderskeid heer en slaaf, bly nog ryk aan kasuïstiek en vertoon nog weinig tekens van die verdieping wat die toenemende kerstening later meegebring het. Tog is die spore van die Romeinse reg diep in die moderne regstelsels, ook die Suid-Afrikaanse, te vinde - Personereg, Familiereg, Erfreg, Sakereg en Verbintenisreg dra elk in meerdere of mindere mate die onmiskenbare stempel van die jus Romanum. 
Ons huidige Sakereg is trouens met weinig gemaakte aanpassings nog steeds Romeins. Ons kontraktereg ken nog steeds die beneficia excussionis et divisionis en die voorregte van die vrou kragtens die Senatus Consultum Vellejanum en die $\mathrm{Au}$ thentica si qua mulier by borgtog, die actio redhibitoria en die actio quanti minoris by verborge gebreke van verkoopsgoedere, om maar 'n paar te noem. Die actio injuriarum en die actio legis Aquiliae bly nog steeds die voedingsbodem vir die Deliktereg - in so ' $n$ mate dat selfs die moderne strewe na die ontwikkeling van so 'n afsonderlike Persoonlikheidsreg nie heeltemal kan loskom van die actio injuriarum nie. Hiermee het ek heel kort die invloed van die Romeinse reg op die juridiese aspek van ons kulturele erfenis gegee - meer besonderhede sal ons te diep voer in die ingewikkelde besonderhede eie aan die Romeinse reg.

Wat nou van die invloed van die Romeinse reg op ander aspekte van ons beskawingspatroon?

Miskien oordrewe en sekerlik ook nie sonder paapse trots in die setel van die Vatikaan, besing Pous Pius XII op Paasdag 1948 Rome as die moeder, die verkondigster en die beskermster van beskawing en van ewige lewenswaardes. Dat ook die reg hier sy rol vervul het, val nie te betwis nie. Ek beperk my egter tot twee funksies wat die Romeinse reg deels direk deels indirek in die kulturele ontplooiing vervul het, nl. die invloed op die taal en die rol by die verbreiding van die Christendom.

Die Twaalf Tafels van $450 \mathrm{v}$. Chr. is die eerste belangrike poging om Latyn in geskrif weer te gee. Soos die Bybelvertaling deur Luther die Duitse taal wesenlik beïnvloed het, het die taal van die Twaalf Tafels die Romeinse styl deurdrenk. Die Romeinse jeug het in die tyd van Cicero nog die Twaalf Tafels gememoriseer - dat dit in besondere mate die taal en taalgebruik moes beïnvloed behoef geen betoog nie. In „A Companion to Latin Studies" (bl. 299) tref ons die volgende ter saaklike stelling aan: „There is no language or literature into which legal conceptions enter so deeply as the Roman. The texture of Roman political history is interpenetrated by law to a degree which can hardly be paralleled. There is much both in the development of the Roman State, and in the details of Latin literature (even where it has no direct con- 
nection with law) which will escape the notice of a student ignorant of the nature and history of legal institutions".

Vanweë die feit dat die Romeinse reg 'n oorheersende plek gaan inneem het oor die ganse Wes-Europa, het die Latynse taal ook as die medium waarin hierdie reg vervat is, die algemeen gebruiklike regstaal geword. Twee voorbeelde behoort $\mathrm{u}$ te oortuig. Hugo de Groot se "Inleiding tot de Hollandsche Rechtsgeleerdheid", wat soos die titel aandui in Nederlands geskryf is, is nog in 1793-1794 deur D. G. van der Keesel geannoteer in Latyn. In Engeland skryf Bracton sy werk oor die wette en gewoontes van die Engelse in Latyn, wat te meer verbaas omdat Engeland nie die invloed van die Romeinse reg ondergaan het nie. Dat Latyn behalwe die regstaal ook die algemeen gebruiklike akademiese taal was, is ek my wel van bewus maar dat die reg ook hierin 'n rol gespeel het, is gewis. Die vraag mag nou allesins tereg gevra word: wat het die Romeinse reg en die Latynse taal met ons huidige beskawingspatroon te make? Die antwoord wil ek kort stel: Hy wat meen Afrikaans, Engels, Duits, Frans en ander Wes-Europese tale waarlik te ken sonder 'n basiese kennis van Latyn, bevind hom in 'n grot waar slegs 'n strepie lig deur 'n rotsgleuf hom bereik. Hy weer wat Latyn meen onder die knie te hê sonder ' $n$ basiese kennis van die Romeinse reg het nog veel te leer. Terloops, dit is interessant om te weet dat die geding waarin Shylock sy pond vleis eis soos verhaal in Shakespeare se "Merchant of Venice" niks anders is as ' $n$ reste uit die Romeinsregtelike siviele gyseling van 'n skuldenaar nie.

Hoe nou hou die Romeinse reg verband met die verbreiding van die Christendom? Die geskiedenis van Konstantyn die Grote se bekering tot die Christendom is bekend. In $313 \mathrm{n}$. Chr. volg die Edik van Milaan, ook soms beskryf as die Toleransedik. Hierin is die Christelike geloof getolereer naas die heidense. Op die oog af lyk dit nie of hierdie edik noemenswaardig veel kon bydra tot die uitbreiding van die Christendom nie feit bly egter dat minder as 70 jaar hierna en wel in 381 na Chr. Theodosius I die Christelike godsdiens kon verhef tot staatsgodsdiens. Hierdeur het uiteraard die bevolking nog nie tot innerlike bekering tot die Christendom gekom nie, maar die deurwerking oor die ganse destyds beskaafde wêreld is seker- 
lik hierdeur op sy minste vergemaklik. Die Christelike geloof het 'n dryfkrag geword agter die werksaamhede van staatsweë en het die rigsnoer geword vir die algemene sedelike bewussyn. Ook die reg het die invloed van die Christendom ondergaan en voortgedra, veral omdat die kerk volgens Romeinse reg geleef het - Ecclesia secundum legem Romanam vivit. Dit kon die kerk omdat die meeste Germaanse stamme die personaliteitsbeginsel erken het en dus Romeinse burgers wat hul in die grondgebied van hierdie stamme bevind het, toegelaat het om volgens Romeinse reg te leef. Hierdie vergunning het ook die kerk ten deel geval omdat die kanonieke reg in wese Romeins is.

Hiermee is ons nou by die Germaanse reg. Die invloed van die Germaanse reg gaan ek met slegs 'n enkele woord afmaak. Nog veel minder as by die Romeinse reg is hier sprake van 'n eenheidsisteem. 'n Algemeen geldende Germaanse reg het nooit bestaan nie, want elke Germaanse stam het volgens eie reg gelewe. Die Germaanse reg is ook dermate deur die Romeinse verdring dat sy invloed veel geringer is. Die feodalisme van die latere Germaanse reg moet miskien beskou word as die vernaamste bydrae van Germaanse kant, hoewel die gevolg daarvan meer verbrokkelend as opbouend was. Hieraan het in elke geval met die Franse Revolusie 'n einde gekom. Spore van die feodalisme tref ons egter vandag nog aan - eienaardig genoeg in Engeland, meer bepaald in die Angel-Saksiese siening van die verhouding van vors tot onderdaan, staatsregtelik en sakeregtelik.

Oor die Romeins-Hollandse reg kan ons eweneens 'n kort woord laat val. As 'n versmelting van Romeinse reg en die inheemse reg van die provinsie Holland (dus Germaanse reg) waarin die Romeinse reg in sterk mate die botoon voer, het die Romeins-Hollandse reg eintlik slegs die Romeinse en Germaanse voortgesit. 'n Belangrike faktor wat hier egter wel vermelding verdien is die Reformasie en sy invloed op die reg. Die kerk het na die Hervorming hom nie meer besig gehou met die wetgewing en regspraak nie. Dit het die Rooms-Katolieke Kerk wel gedoen voor die Reformasie. Die insig dat Kerk en Staat elk 'n eie terrein het, moet dus beskou word as 'n vrug van die Hervorming soos bewerk deur die Calvinisme. Ook die huweliksreg, wat grotendeels beheers was deur 
die Kanonieke reg, het sekere veranderinge ondergaan. Egskeiding is nou toegelaat en wel op 2 gronde, nl. owerspel en kwaadwillige verlating. Daar is vir my persoonlik 'n ernstige vraagteken te plaas agter die wysheid om hierdie tweede grond vir egskeiding, $n l$. kwaadwillige verlating toe te laat. 'n Beroep op 1 Korinthiërs $7: 15$ soos Groenewegen in sy aantekeninge op die reeds vermelde werk van De Groot $(I, 1,5,18)$ doen, lyk my enigsins geforseerd. Hierdie skrifgedeelte het alleen betrekking op 'n situasie waar 'n gelowige deur sy ongelowige eggenoot of eggenote verlaat word. Dat kwaadwillige verlating in ons huidige reg met hierdie skrifgedeelte hoegenaamd geen verband hou nie, is duidelik. Hierdie egskeidingsgrond in ons reg is ongelukkig, vanweë die uyse waarop dit misbruik word, die oorsaak van 'n afbrekende tendens in ons beskawingspatroon.

Sedert 1806 met die tweede Britse besetting van die Kaap het die Engelse reg ' $n$ al hoe belangriker plek in ons regsbedeling gaan inneem. Op 'n somtyds subtiele wyse is die Engelse reg dikwels toegepas ondanks die feit dat die Romeins-Hollandse reg sy gelding bly behou het, paradoksaal genoeg, juis kragtens 'n algemene reël van die Engelse staatsreg wat in die bekende gewysde Campbell v. Hall (98E.R.1045) soos volg geformuleer is: „... the laws of a conquered country continue in force until they are altered by the conqueror". Tog het die Suid-Afrikaanse reg in feitlik geen enkele afdeling daarvan Engelse invloed gespaar gebly nie, hoewel 'n frisse kentering in die afgelope twee of drie dekades te bespeur is.

Veral dominerend is die Engelse inslag in ons staatsreg, prosesreg, bewysreg en handelsreg.

Staatsregtelik is ons parlementêre en politieke lewenswyse geskoei op Engelse lees. Dit tot so 'n mate dat 'n Suid-Afrikaner geen moeite het om politieke strominge in Engeland te volg nie - die Europese politiek daarenteen bly vir die deursnee burger van ons land 'n duistere boek.

Ons prosesreg en bewysreg is so Engels dat 'n Britse juris nie die minste moeite sal ondervind om dit onder die knie te kry en te verstaan nie.

Wat die Handelsreg betref meen ek dat die Engelse invloed in ' $n$ gunstige lig gesien kan word. Handel en nywerheid het in Engeland altyd ' $n$ baie belangrike rol gespeel, en die toe- 
nemende handelsverkeer, veral toe die Britse ryk so 'n groot deel van die aardbol uitgemaak het, het vanselfsprekend telkens aanpassings in die reg, meer bepaald in wetgewing geverg. Hierdie wetgewing is in vele gevalle feitlik woordeliks deur die Suid-Afrikaanse wetgewer nagevolg. Ek noem slegs 'n paar die maatskappywet, die versekeringswet, die wisselwet en tot 'n mate ook die wet op die Suid-Afrikaanse Spoorweë en Hawens en die Huurgeldewet. Die handel maak vandag so 'n belangrike deel van ons beskawingspatroon uit dat daar sonder die minste huiwering beweer kan word dat hierdie wetgewing in 'n baie sterk mate ons lewenspatroon beïnvloed.

Ten slotte dan, kom ek nou by die moderne Suid-Afrikaanse reg en sy invloed op ons beskawingspatroon. Vir die doel kies ek maar slegs enkele aspekte.

"The two main factors in shaping modern South Africa are the rift between the two white sections and the schism between White and Non White. The conflicts and reconciliations of these sections make up much of South Africa's history and have left their permanent stamp on her laws and institutions" verklaar Hahlo (Hahlo and Kalm: „The Union of South Africa - The development of its laws and constitutions").

Twee landstale, twee vlae, twee hoofstede, 'n tweeslagtige burgerskap en twee standaarde van lojaliteit was die produk van wetgewing wat allerlei onversoenlike en soms kleinlike standpunte moes probeer versoen. Aan hierdie dubbelslagtigheid het daar gelukkig deur wetgewing 'n einde gekom, hoewel ons landsvlag in sigself nog steeds die gees van kompromie vertoon. Dit val dan ook nie te ontken dat Suid-Afrikaners oor die algemeen die landsvlag nie met dieselfde warmte bejeën as wat die geval is met bv. die Franse of Nederlanders teenoor hul landsvlae respektiewelik nie.

Dink ' $n$ mens aan wetgewing of wetgewingstendense wat 'n tipies Suid-Afrikaanse karakter dra, gaan die gedagtes as vanself na die kleurslagboom en hoe dít in ons apartheidswetgewing beliggaam word. Iemand wat nie presies weet waar om Suid-Afrika op die wêreldkaart te plaas nie is nie so ' $n$ rariteit as iemand wat nog nooit van apartheid gehoor het nie. Die invloed van hierdie wetgewing is sekerlik nie in ' $n$ paar woorde te oorsien nie - dit oorheers nie alleen ons eie politieke denke nie maar vind ook, in reaksie, 'n plek in die 
politieke denke in ander lande. $U$ bekendheid met die uitwerking van hierdie wetgewing maak dit onnodig om op alle besonderhede in te gaan. Tog wil ek daarop wys dat die rol van die wetgewing in die verband maklik oorskat kan word. Apartheid is nie slegs 'n gevolg van wetgewing nie. Trouens hierdie wetgewing bestendig tot 'n groot mate 'n lewenspatroon wat reeds bestaan het. Gemengde huwelike bv. het slegs by hoë uitsondering voorgekom voordat dit by wetgewing verbied is. Sosiale verkeer tussen blank en nie-blank kom vandag miskien meer voor as in die tyd voordat die wetgewing voorskrifte in die verband gepromulgeer het, en wel omdat met die toename in apartheidswetgewing 'n toename in linkse elemente saamgeval het. Ek wil hieer nie verkeerd begryp word nie - ek beweer geensins dat die apartheidswetgewing oorsaak is van die toename in linkse elemente nie: ek konstateer slegs die feit dat daar 'n gelyktydige toename van apartheidswetgewing en linkse groepvorming plaasgevind het. Aan die ander kant wil ek ook nie die oë sluit vir die feit dat aksie reaksie uitlok en dat Suid-Afrika ook die invloed van buite ondervind nie. Hierdie sterk gevoel teen apartheid in die buiteland het uiteraard sy navolgers in ons land. Terwyl ons besig is met die antipatieke gees van die buiteland teenoor apartheid is dit nie van alle belang ontbloot nie om te weet dat die skreeuende tirade teen Suid-Afrika ook weer te wyte is aan ' $n$ reaksie en wel teen die gees van die Nasionaal-Sosialisme van vooroorlogse Duitsland. Apartheidswetgewing en die rassewetgewing uit die Hitler-periode word sonder enige diepgaande studie op een voet gestel.

Die fenomenale ontwikkeling van die nywerhede in SuidAfrika het ook meegebring dat die wetgewer besig gebly het. Hieroor 'n paar woorde. Ons nywerheidswetgewing bevorder in geen geringe mate vreedsame en deurlopende nywerheidsaktiwiteite. Dat ons veel minder stakings beleef as vele ander lande moet direk in verband gebring word met die billike reëling insake nywerheidsgeskille soos vervat in ons nywerheidswetgewing, meer bepaald in die Wet op Nywerheidsversoening, die Wet op Naturelle Arbeid (beslegting van geskille) en die Loonwet. Vir die beslegting van nywerheidsgeskille word voorsiening gemaak in 'n wye reeks van alternatiewe en opeenvolgende middele wat aangewend kan word. Oor die algemeen 
word die beslegting van geskille verkry deur onderhandeling tussen werkgewers en werknemers. Hoe hierdie onderhandeling moet plaasvind is gereël in die wette reeds genoem. deling moet plaasvind is gereël in die wette reeds genoem.

Met veel vrug sou ons nog kan ingaan op die volgende besondere invloedsaspekte van die reg: die invloed van die strafreg in die bekamping van misdaad, die invloed van wetgewing op die onderdrukking van Kommunisme, die wetgewing met betrekking tot die bekamping van ongewenste publikasies, ongewenste kleredrag, en ongewenste gedrag, die lasterreg en sy invloed op die pers, wetgewing i.v.m. die billike toebedeling van water, om maar enkeles te noem. Ek volstaan egter met die paar fasette wat ek met $u$ bespreek het. Ek wil toegee dat my keuse enigsins willekeurig is en in vele opsigte miskien fragmentaries aandoen. Volledigheid is egter nie moontlik binne die tydsbeperking deur 'n lesing gestel nie.

'n Geskikte slot wil ek soek in 'n taakstelling vir die toekoms. Daar is reeds gewys op die feit dat die reg nie graag voorloop nie. Die akademiese juris meen ek egter kan en moet ook die wetgewer voor wees in die raaksien van wat in die toekoms noodsaaklik is. Veranderende omstandighede bring noodwendig aanpassing en verandering in die reg mee. Die reg moet dus rekening hou met veranderinge, maar nie deur die veranderinge meegesleur word nie, want alle verandering is nie verbetering nie. Daar is gelukkig iets anders waarmee die reg rekening moet hou en dit verander nooit nie. Gods Woord moet ook vir die reg 'n vaste rigsnoer bly. Die volgende behartenswaardige woord van Stoker (H. G. Stoker: Beginsels en Metodes in die wetenskap, bl. 194) bly ook vir die juris en sy siening op die beskawing waar: ,'n onontwikkelde, ongeleerde, kultuurarme ou moedertjie wat in haar vreugde en sorge met 'n gelowige hart haar tot God rig, is veel egter, inniger en dieper mens as 'n genie wat alle beska. wing moontlik hom toegeëien het, ryk en magtig is, maar wat hom oor God en sy gebod nie bekommer nie". Op geen ander wyse as met Gods Woord as vaste fondament kan 'n gelowige juris die reg aanwend tot beskawing van wat nog nie beskaafd is nie, en aanwend as ' $n$ haltroep tot dit wat wanbeskaaf geraak het. Dit is die taak van die regsfakulteit aan 'n universiteit wat tot leuse het: „In u lig sien ons die lig". S. Postma. P. U. vir C.H.O.

S. Postma. 